\title{
Grass Species Diversity and Ground Cover of Herbs in the Grassland Plains of Nech Sar National Park, Ethiopia
}

\author{
Molla Mekonnen Alemu, Subhes Bhattacharyya, Andrew Reeves, Mark Lemon \\ De Montfort University, Leicester, UK \\ Email: mollamekonnen@gmail.com
}

How to cite this paper: Alemu, M.M., Bhattacharyya, S., Reeves, A. and Lemon, M. (2017) Grass Species Diversity and Ground Cover of Herbs in the Grassland Plains of Nech Sar National Park, Ethiopia. Journal of Environmental Protection, 8, 250-257. https://doi.org/10.4236/jep.2017.83019

Received: February 4, 2017

Accepted: March 12, 2017

Published: March 15, 2017

Copyright (c) 2017 by authors and Scientific Research Publishing Inc. This work is licensed under the Creative Commons Attribution International License (CC BY 4.0).

http://creativecommons.org/licenses/by/4.0/

\begin{abstract}
Natural ecosystems harbor a variety of landscapes which are significantly important for the continuation of life forms on planet earth. Grasslands are natural habitats dominated by grasses and may contain few trees and shrubs. In the context of protected areas, these resources form the basic foundation for the availability of food in an ecosystem as it plays a magnificent role for the survival of herbivore wild animal and the entire food chain. In many protected areas, including Nech Sar National Park, these ecologically valued resources are facing functional challenges due to the competition for resources. Local communities usually see these resources as the green pasture to feed their livestock and hence compete with the scarce feed resources which are meant for wild animals. This study was aimed to explore the effect of livestock pressure on the availability of grass by examining the proportion of ground cover of herbs and different species of grass. The research also tried to identify the type of grass species in the Nech Sar grassland plain area of the Park. So as to gather information, 38 experimental plots measuring $3 \mathrm{~m} \times 3 \mathrm{~m}$ were deployed along with 2 transect lines. Analysis of the finding shows that, the livestock pressure in the area is having a significant impact on the availability of feed for the wild animals. In the experimental plots, livestock related pests like ticks were also observed. Therefore, immediate actions which could stop the entrance of the livestock to the grassland need to be placed if the ecology of the Park has to continue providing its intended ecosystem services.
\end{abstract}

\section{Keywords}

Grass, Wildlife, Diversity, Herbs, Nech Sar

\section{Introduction}

Healthy and properly functioning biodiversity resources have the power to de- 
liver the natural services of ecosystems to humanity. According to the Convention on Biodiversity, "at least 40 percent of the world's economy and 80 percent of the needs of the poor are derived from biological resources. In addition, the richer the diversity of life, the greater the opportunity for medical discoveries, economic development, and adaptive responses to such new challenges as climate changes" [1].

Biodiversity resources are the driving forces for the proper functioning of ecosystems. Hence, different life forms on earth could enjoy soil and water protection, nutrient recycling, breakdown of toxic substances and their absorption, stabilizing climatic effects, risk and disaster prevention and many more.

As a direct benefit to humans, healthy biodiversity resources will serve by being sources of food, feed, medicinal values, timber products, aesthetic value, and serve also as gene bank for the continuity of future fauna and flora populations.

Well managed and protected biodiversity resources also ensure local as well as regional economic development efforts. A healthy ecosystem, for instance, helps to ameliorate adverse local climatic factors and can create an agroecology which is conducive for the growth of crops and animals. The use of trees as windbreaks and shelterbelts can be mentioned as an example with this regard.

The non-smoke industry, tourism, is also supporting the livelihoods of many in different parts of the world as a result of the proper functioning of natural ecosystems that are aided by the existence of diverse faunal and floral species.

Protected areas like National Parks are sinks for the different sets of all these wealthy resources. As been pointed out by Shah [2], species depend on each other for their survival while there will be "survival of the fittest"; life in natural ecosystems will continue by its actual mode of "wilderness" and thereof enable the ecosystems to deliver their natural services.

Protected areas could harbor different habitats like grasslands, aquatic resources, trees, shrubs and a wide range of species in the Animalia Kingdom. The sustenance of each segment will depend on the wellbeing of each element in the food chain.

Biodiversity can be considered as the amount and type of faunal and floral species in an area. It can also be considered as an indicator for the health of ecosystems and the services they provide. The decline in the amount of frogs in an ecosystem could mean as there is something wrong in the natural systems, this can on the other side change the population structure of others which depend on the availability of frogs.

Humans, however, have interfered these natural cycles and posed a threat on the proper functioning of the ecosystems. This is mainly attributed by the elimination of natural habitats so as to meet the increasing demands of the growing population in the form of the expansion of agricultural lands and settlement areas, energy demand and the need for shelter and construction materials [3].

The Nech Sar grassland plains of Nech Sar National Park is the major source of feed for a wide range of herbivores, this includes the Burchell's zebra, Swayne's hartebeest and others. This precious land resource, however, is being affected by the competing interference of the local community's high livestock 
pressure and hence, the study is deemed relevant so as to explore the challenges of the park.

The heavy livestock pressure will always be deployed in the grassland and compete for the available resources that was meant to be the source of feed for the wild animals. As a result of the frequent in and out movement of the livestock, the grassland is also being invaded by invasive alien plant species like Abutilon species. This study is, therefore, aimed at exploring the proportion of ground cover of herbs in the controlled and the livestock interfered settings which will enable development actors so as to gauge the severity and magnitude of the problem and take the necessary actions which will enable to reverse the situation. Hence, this study is aimed at exploring the effect of livestock pressure on the availability of feed by examining the proportion of ground cover of herbs and different species of grass. The research is also aimed at identifying the type of grass species in the Nech Sar grassland plain area of the Park.

\section{Methodology}

\subsection{Description of the Study Area}

Nech Sar National Park is located in the Southern Ethiopia $510 \mathrm{~km}$ south of Addis Ababa. The park lies within the floor of the Great Rift Valley and extends from $5^{\circ} 51^{\prime} \mathrm{N}$ to $6^{\circ} 50^{\prime} \mathrm{N}$ and from $37^{\circ} 32^{\prime} \mathrm{E}$ to $37^{\circ} 48^{\prime} \mathrm{E}$ with an elevation varying between 1108 - 1650 meters above sea level. The park is bounded to the east by the spectacular Amaro Mountain, to the west by the town of Arbaminch and to the north and south by lakes Abaya and Chamo respectively (Figure 1). Arbaminch is the sprawling, principal town of GamoGoffa administrative zone, located at the base of the western side of the Great Rift Valley in the Southern Nations, Nationalities and peoples' Regional State of Ethiopia and which is found at an average elevation of $1285 \mathrm{~m}$ above sea level [4].

The Park situated in an area of great natural beauty in the mid rift valley was established in 1974 by covering an area of $514 \mathrm{~km}^{2}$, of which $78 \mathrm{~km}^{2}(15 \%)$ of total coverage is water. Nech Sar named after the white grass, its name was derived from two Amharic words "Nech" meaning "White" and "Sar" meaning "Grass" as the color of the grass which covers the undulating Nech Sar plain during the dry season gives the landscape a yellow-white color. Among the fascinating landmarks situated inside the park is the "forty spring" whereby the name of the town Arba Minch itself is derived from the two Amharic words ("Arba" means "forty" and "Minch" means "Springs") as a result of the existence of the forty springs in one particular place under the canopies of the Ground Water Vegetation of the Park [5].

\subsection{Data Collection and Analysis}

In order to estimate the abundance of the major herbaceous plant species in the Nech Sar grassland plains of the Park, 38 experimental plots measuring $3 \mathrm{~m} \times 3$ $\mathrm{m}$ were placed along 2 transects. In these plots, the proportion of cover by each herbaceous species was estimated visually [6] [7]. Thus, in order to know the 


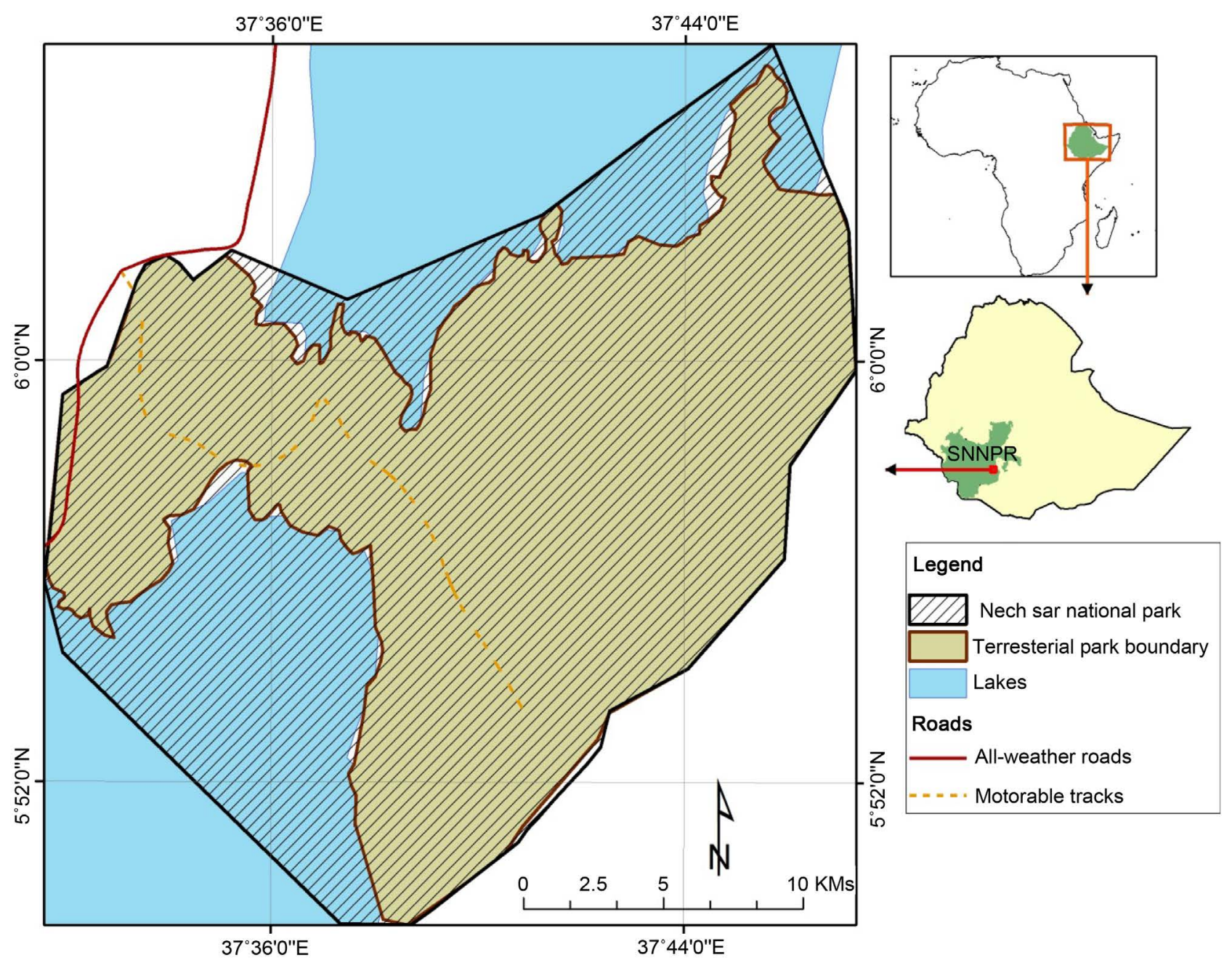

Figure 1. Location map of Nech Sar national park [4].

major herbaceous species, two classes were predetermined based on the reconnaissance survey as follows, Class I ( $80 \%-100 \%$ controlled) and Class II $(0 \%$ $70 \%$ livestock interfered).

One of the well-organized camp sites of the park is located in the Nech Sar Grassland plain and in the nearby locations of the camp site, there is no livestock interference as the park rangers will always be around to take all the legal actions and hence that portion of the area is categorized as Controlled area since it has a very dense proportion of the ground cover. To the contrary as we proceed to the middle of the grassland and then towards the peripheries one can easily observe the livestock pressure competing with the feed of the wild animals and that are of the park according to this study is categorized as Livestock Interfered since the landscape has a thin proportion of the ground cover. The collected data was organized in these two categories. Data was then analyzed in order to see the level of significance on the proportion of ground cover of herbs on the controlled and the livestock interfered land management settings by making use of the statistical software, SAS. The grass species in the grassland were also identified. 


\section{Results and Discussion}

Ground cover is one of the most important habitat components of conservation areas [8]. However, its importance for wild life depends on the quality of species that constitute the cover. Even though, this study didn't go through the quality aspect of it, but it is tried to identify the major grass species of the park. 20 grass species were identified in the Nech Sar grassland plains of the Park (Table 1) and of which Chrysopogon plumulosus and Bothriochloa insculpta are the most dominant grasses in the area.

The Nech Sar grassland plain is an area which used to be dominated by grasses. It is a landscape which supports a diverse faunal and floral species. It covers a total area of about $270 \mathrm{~km}^{2}$ which is about $52.5 \%$ of the total area of the park. Bothriochloa insculpta and Chrysopogon plumulosus are the dominant grass species of the grassland. Burchell's Zebra, Swayne's Hartebeest, Grant's gazelle, Greater Kudu and Hunting Dog are also among the wild animals that dominate the area. The results of the one way analysis of variance (ANOVA Table 2 and Table 3) from SAS, however, showed that the grassland is under immense livestock pressure and the availability of feed for the wild animals is being threatened at an alarming rate as the proportion of the ground cover of herbs is getting thin in the major segment of the grassland.

Table 1. Grass species identified from the Nech Sar plains of the park.

\begin{tabular}{ccc}
\hline S.N. & Scientific name & Remark \\
\hline 1 & Chrysopogon plumulosus & Dominant \\
2 & Bothriochloa insculpta & $2^{\text {nd }}$ dominant \\
3 & Digitaria macroblephara & \\
4 & Lintonia nutans & \\
5 & Sehima nervosum & \\
6 & Brachiaria deflexa & \\
7 & Heteropogon contortus & \\
8 & Cenchrus ciliaris & \\
9 & Aristida kenyensis & \\
10 & Chloris virgata & \\
11 & Ischaemum afrum & \\
12 & Cynodon nlemfuensis & \\
13 & Tetrapogon villosus & \\
14 & Eragrostis tremula \\
15 & Setaria incrassata & \\
16 & Themeda triandra & \\
19 & Cynodon dactylon & \\
\hline & Brachiaria serrata & \\
\hline
\end{tabular}


Table 2. The MEANS procedure for the analysis of variables.

\begin{tabular}{ccccc}
\hline Variable & Obs & $\mathrm{N}$ & Mean & Std. Error \\
\hline Control & 17 & 17 & 91.82 & 1.71 \\
Livestock Interfered & 21 & 21 & 44.28 & 4.01 \\
\hline
\end{tabular}

Table 3. ANOVA for the controlled and livestock interfered area of the grassland.

\begin{tabular}{cccccc}
\hline Source & DF & SS & Mean Square & F Value & Pr $>$ F \\
\hline Model & 1 & 21230.6 & 21230.6 & 101.09 & $<0.0001$ \\
Error & 36 & 7560.7 & 210 & & \\
$\begin{array}{c}\text { Corrected } \\
\text { Total }\end{array}$ & 37 & 28791.3 & & & \\
\hline
\end{tabular}

The one way ANOVA also showed as the livestock pressure is having a significant effect on the availability and proportion of the ground cover of herbs which is meant to be the source of feed for the precious wild animals of the par $(\mathrm{P}<0.05)$.

Apart from the direct grazing of the livestock in the grassland, on the western side of the park, the local communities and Arba Minch city inhabitants are mowing a huge amount of grass out of the park through the illegal cut and carry system.

The park shares a direct border with 7 rural Kebeles (the smallest administration unit of the country)-Ergensa, D. Menena, Tfatie, Yero, Alfacho, Abulo, GantaLeto and the city of Arba Minch (Table 4). Since pastoralism is the main stay of livelihood for these local communities, they highly depend on the vegetation of the park to feed their livestock. This in turn is affecting the ecosystem since the natural food chain is being disturbed by the diminishing availability of feed for the herbivores and increasing proportion of bare ground (Figure 2 and Figure 3).

Table 4. Number of livestock in all the bordering localities of Nech Sar Park [9].

\begin{tabular}{ccccccccc}
\hline S.N & $\begin{array}{c}\text { Name of } \\
\text { Kebele }\end{array}$ & Cattle & Goat & Sheep & Horse & Donkey & Mule & Total \\
\hline 1 & Ergensa & 26,700 & 4200 & 290 & - & 160 & --- & 31,350 \\
2 & D. Menena & 4435 & 3936 & 3675 & 154 & 26 & 15 & 12,241 \\
3 & Tfatie & 4657 & 1298 & 278 & 11 & 24 & 14 & 6282 \\
4 & Yero & 3323 & 1265 & 89 & 5 & 28 & 8 & 4718 \\
5 & Alfacho & 5627 & 1805 & 41 & -- & 16 & -- & 7489 \\
6 & Abulo & 1426 & 611 & 5 & -- & 0 & -- & 2042 \\
7 & GantaLeto & 1024 & 622 & 123 & --- & 73 & --- & 1842 \\
8 & Arba & 3264 & 443 & 185 & --- & 23 & -- & 3915 \\
& Minch city & & & & & & & \\
& Total & 50,456 & 14,180 & 4686 & 170 & 350 & 37 & 69,879 \\
\hline
\end{tabular}



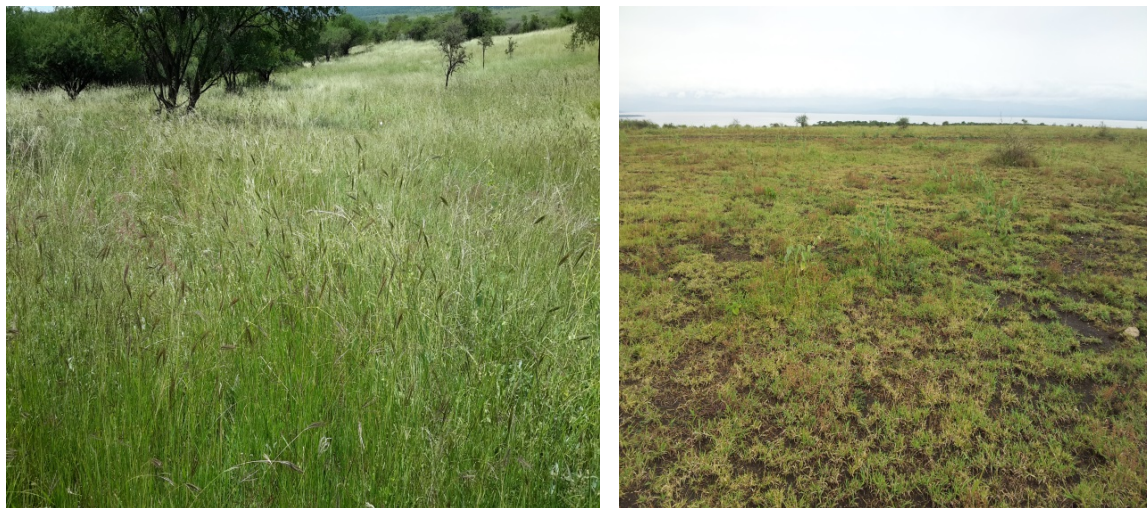

Figure 2. Dense coverage of grass in the protected (left) and the degraded coverage of grass area of the park (right) - photos taken on same day (July 16, 2016).
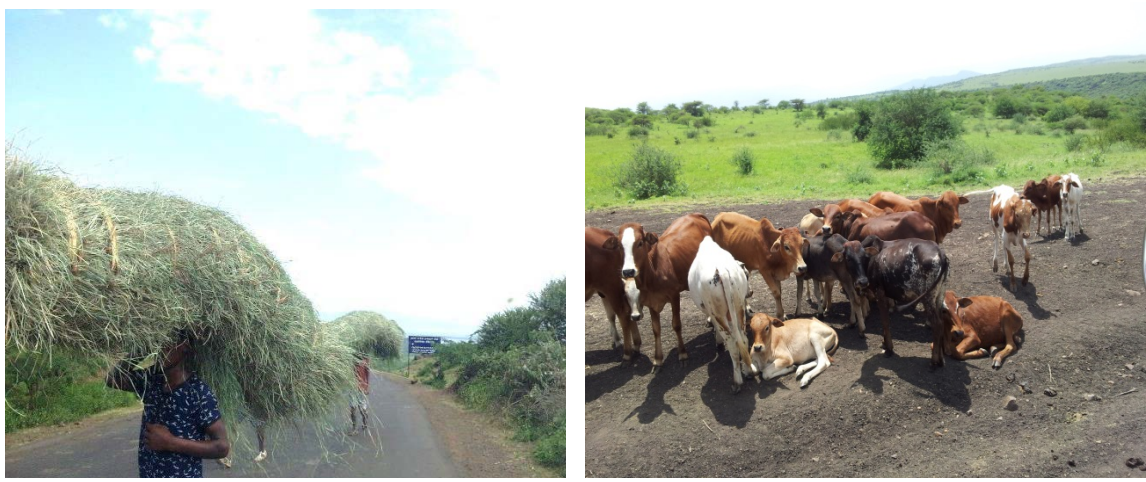

Figure 3. Illegal cutting of grass from the Park and cattle population inside the Park.

In general, it possible to say that the ground vegetation of the grassland is well eaten by livestock pressure due to the prevailing fact that the major part of the grassland carries too many domestic animals of the different tribes, and overgrazing and erosion is apparent in many places. Thus, the increased proportion of bare ground is the end result of long and continuous overgrazing by the livestock population inside the territories of the park.

\section{Conclusion}

Nech Sar National Park is cherished for its immense biodiversity resources. The Park, however, is facing natural resources degradation as a result of the human interference in the form of overgrazing expansion of agricultural activities and settlements. In the livestock interfered areas of the Nech Sar grassland, the major portion of the ground is found to be in poor cover which is directly related to the presence of high livestock population grazing on it as well as the associated trampling effects from the cattle. The poor ground cover of herbs coupled with the competition for feed from the livestock pressure will have a direct effect on the existence, diversity and density of the wildlife population of the park. Therefore, since protected areas are meant to conserve the natural heritages along with the biodiversity resources, the impact of the pastoral communities on Nech Sar National Park needs to be averted by creating the enabling environment for the 
development of alternative livelihoods. Developing the awareness of the local community members on the importance of the park towards local and regional climate impacts could also help to lower down the human interference challenges into the park. Law enforcement and having a legalized boundary of the park are also issues that need to be addressed by the decision and policy makers of the sector.

\section{References}

[1] CBD (The Convention on Biological Diversity) (2016) The Convention about Life on Earth. http://darwin.bio.uci.edu/sustain/bio65/lec06/bio-leaf.htm

[2] Anup, S. (2014) "Why Is Biodiversity Important? Who Cares?" Global Issues. http://www.globalissues.org/article/170/why-is-biodiversity-important-who-cares

[3] Dunn, C. (2010) Biodiversity: The Importance of a Varied Ecosystem. Greener Ideal.

https://greenerideal.com/science/6994-biodiversity-the-importance-of-a-varied-eco system/

[4] Zafu, B. (2015) Assessment of Factors Affecting Tourist Satisfaction in Arba Minch Town, A Case Study of Nech Sar National Park. Arba Minch, Ethiopia.

[5] Desse, A.M. (2015) Summary of Attractions, Challenges, Research, Management and Partnership Issues on Nech Sar National Park. Arba Minch, Ethiopia.

[6] Sutherland, W.J. (2000) Ecological Census: A Handbook. Cambridge University Press, Cambridge.

[7] Birhane, E. (2002) Actual and Potential Contributions of Enclosures to Enhance Biodiversity in Dry Lands of Eastern Tigray, with Particular Emphasis on Woody Plants. MSc Thesis, Swedish University of Agricultural Sciences, Sweden.

[8] Mekonnen, A. (2005) Wildlife Habitat Quality Assessment in Three Sites of Awash National Park, Eastern Ethiopia, Wondo Genet, Ethiopia.

[9] Marye, A. (2014) Nech Sar National Park Demarcation. Arba Minch, Ethiopia.

\section{Scientific Research Publishing \\ Submit or recommend next manuscript to SCIRP and we will provide best service for you:}

Accepting pre-submission inquiries through Email, Facebook, LinkedIn, Twitter, etc. A wide selection of journals (inclusive of 9 subjects, more than 200 journals)

Providing 24-hour high-quality service

User-friendly online submission system

Fair and swift peer-review system

Efficient typesetting and proofreading procedure

Display of the result of downloads and visits, as well as the number of cited articles

Maximum dissemination of your research work

Submit your manuscript at: http://papersubmission.scirp.org/

Or contact jep@scirp.org 